\title{
CONFLICT INTEREST YANG DISEBABKAN MORAL HAZARD DALAM PERUMUSAN KEBIJAKAN MORATORIUM PAILIT DAN PKPU
}

\author{
Evi Dwi Hastri ${ }^{(1)}$ \\ Rusfandi $^{(2)}$ \\ ${ }^{(1,2)}$ Dosen Fakultas Hukum Universitas Wiraraja \\ evidwihastri@wiraraja.ac.id ${ }^{(1)}$ \\ rusfandi@wiraraja.ac.id ${ }^{(2)}$
}

\begin{abstract}
ABSTRAK
Konsep moral hazard dikonotasikan sebagai perilaku ketidakjujuran seseorang yang dapat meningkatkan kemungkinan terjadinya kerugian. Kerugian yang dimaksud adalah tidak mampu melakukan kewajiban pembayaran utang terhadap beberapa kreditor yang telah cukup waktu untuk dibayarkan. Perilaku moral hazard ini dapat dijadikan sebagai modus untuk menyelesaiakan permasalahan utang terutama ditengah pandemi Covid-19. Masalah moral hazard merupakan bentuk penyimpangan. Sehingga dari kondisi yuridis inilah dapat diketemukan suatu permasalahan lain yakni ketika model atau cara moral hazard dalam konflik kepentingan (Conflict Interest) dijadikan sebagai modus untuk memanfaatkan adanya perumusan kebijakan moratorium pailit dan PKPU berdasarkan Undang - Undang Nomor 37 Tahun 2004 Tentang Kepailitan Dan Penundaan Kewajiban Pembayaran Utang. Metode penelitian hukum yang digunakan adalah yuridis normatif dengan pendekatan perundang undangan (Statute Approach). Metode pengumpulan dan pengolahan bahan hukum menggunakan Library Research. Analisis bahan hukum yang dipergunakan yaitu deskriptif analitis. Perumusan kebijakan moraturium pailit dan PKPU bukan merupakan hal yang urgen untuk diberlakukan dalam bentuk Perppu. Apabila kebijakan ini diberlakukan maka secara yuridis otoritas legal untuk permohonan pengajuan pailit dan permohonan PKPU berada di tangan Pemerintah. Berdasarkan konsep Law As Tool Of Social Control, maka sudah sejatinya produk hukum yang dilahirkan tidak hanya ditujukan untuk keuntungan pihak yang berkepentingan. Melaikan dapat dijadikan anomali berperilaku yang tidak menyebabkan kerugian pihak lain.
\end{abstract}

Kata Kunci : Moral Hazard, Kebijakan Moratorium, Pailit Dan PKPU 


\section{IURNAL JENDELA HUKUM}

\section{A. PENDAHULUAN}

Dunia perekonomian tidak pernah lepas dari adanya persaingan, baik persaingan internal maupun eksternal. Adanya situasi ini mendikotomi antara kepentingan korporasi dan kepentingan pribadi. Namun, demi kepentingan korporasi berdasarkan hubungan ruang lingkup korporasi yang melibatkan beberapa individu didalamnya menjadikan area ini tidak lagi murni demi kepentingan bersama. Hal ini dapat terjadi apabila ada salah satu pihak yang tidak mengetahui tujuan dan keinginan yang dikehendaki oleh pihak yang lainnya.

Akibat perbuatan dari pihak-pihak berkepentingan yang mempengaruhi eksistensi korporasi sehingga akan berdampak pada keberlangsungan dan stabilitas kondisi korporasi tersebut dikenal dengan moral hazard. Konsep moral hazard dikonotasikan sebagai perilaku ketidakjujuran seseorang yang dapat meningkatkan kemungkinan terjadinya kerugian. Kerugian yang dimaksud adalah tidak mampu melakukan kewajiban pembayaran utang terhadap beberapa kreditor yang telah cukup waktu untuk dibayarkan.

Perilaku moral hazard ini dapat dijadikan sebagai modus untuk menyelesaiakan permasalahan utang terutama ditengah pandemi Covid-19. Dimana saat ini para pelaku usaha
ISSN Cetak E Online : 2355-5831/ 2355-9934 mengusulkan kepada pemerintah untuk mengeluarkan kebijakan moratorium pailit dan Penundaan Kewajiban Pembayaran Utang (PKPU). Seperti yang dilansir dari kontan.co.id : "Menteri Koordinator Bidang Perekonomian Airlangga Hartarto mengatakan, pemerintah saat ini tengah mengkaji usulan pengusaha terkait menghentikan sementara atau moratorium pengajuan penundaan kewajiban pembayaran utang (PKPU) dan kepailitan."1

Pailit dan kepailitan berawal dari ketidakmampuan membayar namun dalam praktiknya sering menjadi ketidakmauan debitor untuk membayar utang-utangnya yang telah jatuh waktu tempo dan dapat ditagih. Jika debitor berada dalam kondisi demikian, maka debitor, kreditor ataupun pihak lain yang ditentukan didalam peraturan perundang-undangan dapat mengajukan permohonan pailit ke pengadilan. ${ }^{2}$ PKPU sendiri dapat diajukan oleh debitor maupun oleh kreditornya. Ketentuan kreditor dapat mengajukan

${ }^{1}$ Vendy Yhulia Susanto, 2021, Para pakar soroti wacana moratorium pengajuan PKPU dan Kepailitan, diakses dari https://nasional.kontan.co.id/news/para-pakarsoroti-wacana-moratorium-pengajuan-pkpu-dankepailitan pada tanggal 02 September 2021 Pukul 13.08 WIB

2 Ridwan Khairandy, 2013, Pokok-Pokok Hukum Dagang Indonesia, FH UII Press, Yogyakarta, hlm. 457 


\section{JURNAL JENDELA HUKUM}

ISSN Cetak E Online : 2.355-5831/ 2355-99.34

PKPU merupakan ketentuan baru dalam Undang-Undang Kepailitan. ${ }^{3}$

Masalah moral hazard dapat dikatakan sebagai bentuk penyimpangan. Sehingga dari kondisi yuridis inilah dapat diketemukan suatu permasalahan lain yakni ketika model atau cara moral hazard dalam konflik kepentingan (Conflict Interest) dijadikan sebagai modus untuk memanfaatkan adanya perumusan kebijakan moratorium pailit dan Penundaan Kewajiban Pembayaran Utang (PKPU) berdasarkan Undang - Undang Nomor 37 Tahun 2004 Tentang Kepailitan Dan Penundaan Kewajiban Pembayaran Utang.

Menggunakan metode penelitian hukum yuridis normatif dengan pendekatan perundang - undangan (Statute Approach) yakni telaah hukum berdasarkan aturan yang berkaitan dengan permasalahan yang dilakukan analisis. Sehingga metode pengumpulan dan pengolahan bahan hukum adalah menggunakan Library Research atau yang dikatakan studi kepustakaan dengan memasukkan semua bahan hukum baik primer, skunder, maupun tersier. Adapun analisis bahan hukum yang dipergunakan yaitu deskriptif analitis.

\footnotetext{
${ }^{3}$ M. Hadi Subhan, 2008, Hukum Kepailitan Prinsip, Norma, dan Praktik di Peradilan, Kencana, Jakarta, hlm. 147
}

\section{B. PEMBAHASAN}

Secara umum syarat sah yang ada dalam perjanjian telah disebutkan dalam KUHPerdata. Pasal 1320 KUH Perdata disebutkan bahwa untuk sahnya suatu perjanjian diperlukan empat syarat yaitu sepakat, cakap berbuat, hal tertentu dan sebab yang halal. Dua syarat yang pertama adalah syarat subyektif, yakni bersangkut paut mengenai subjeknya yang melakukan perjanjian, selanjutnya adalah syarat obyektif karena menyangkut objek dari perjanjian itu sendiri.

Apabila syarat subjektif tidak terpenuhi maka dapat dibatalkan, dan berikutnya jika syarat objektif yang tidak dapat dipenuhi maka konsekuensinya adalah batal demi hukum.

Ranah hukum perjanjian apabila yang disepakati merupakan perjanjian utang piutang, dimana "utang piutang merupakan perjanjian antara pihak yang satu dengan pihak yang lainnya dan objek yang diperjanjikan pada umumnya adalah uang. Pada pokoknya, terjadinya perjanjian utang piutang ada dua macam, yaitu karena murni perjanjian utang piutang dan karena dilatarbelakangi perjanjian lain."4

Ketidakmampuan membayar utang baik karena belum cukup atau karena banyaknya tanggungan pembayaran

4 Gatot Supramono, Perjanjian Utang Piutang, Cet. I, Penerbit Kencana Prenadamedia Group, Jakarta 2013, hlm. 11. 


\section{IURNAL JENDELA HUKUM}

utang kepada beberapa kreditor dapat berakibat pada kondisi perusahaan. Permasalahan ini dapat menimbulkan kerugian bagi pihak kreditor. "Dilihat dari perspektif kreditor, kewajiban membayar debitor tersebut merupakan "hak untuk memperoleh pembayaran sejumlah uang" atau right to payment."

Segala permasalahan seperti pada contoh diatas harus dapat diselesaikan melalui jalur-jalur hukum. salah satu cara untuk menyelesaikan utang-piutang dengan jalur hukum antara lain melalui perdamaian, alternative penyelesaian sengketa (alternative dispute resolution/ADR), penundaan kewajiban pembayaran piutang, dan kepailitan. Sehingga dengan berdasarkan pada ketentuan pailit sebagaimana yang tertuang dalam Pasal 2 ayat (1) Undang-Undang Kepailitan dan PKPU Nomor 37 Tahun 2004 maka dapat diajukan dan juga mengajuka permohonan Pailit.

Proses acara kepailitan konsep utang sangat menentukan, oleh karena tanpa adanya utang tidaklah mungkin perkara kepailitan akan bisa diperiksa. Tanpa adanya utang tersebut maka esensi kepailitan menjadi tidak ada karena kepailitan adalah merupakan pranata hukum untuk melakukan likuidasi aset

5 Prof. Dr. Sutan Remy Sjahdeini, 2010, Hukum Kepailitan Memahami UU No.37 Tahun 2004 tentang Kepeilitan, Pustaka Utama Grafiti, Jakarta, hlm. 89.
ISSN Cetak E Online : 2355-5831/ 2355-99.34 debitor untuk membayar utang-utangnya terhadap para kreditornya. Dengan demikian, utang merupakan raison d'etre dari suatu kepailitan. ${ }^{6}$

Persoalan pada tulisan ini adalah moral hazard sebagai modus yang dilakukan oleh pihak berkpentingan dalam suatu perjanjian maka hal ini berorientasi pada pemenuhan prestasi. Tindakan menyimpang dalam moral hazard dilakukan setelah semua unsur dalam Pasal 1320 KUH Perdata terpenuhi. Hal ini bukan lagi masalah terpenuhi atau tidak terpenuhi syarat sahnya perjanjian. Namun ini merupakan akibat hukum dari adanya perjajian yang dilakukan atas dasar sepakat.

Sebagai legal substance dalam menyelesaikan permasalahan dalam hukum perikatan khususnya hukum bisnis, maka Undang-Undang No 37 Tahun 2004 tentang Kepailitan dan Penundaan Kewajiban pembayaran Utang disahkan. Setelah berlakunya Fv. S. 1905 No. 217 jo S. 1906 No. 348, Republik Indonesia mampu membuat sendiri peraturan kepailitan meskipun masih tambal sulam sifatnya, yakni sudah ada 3 (tiga) peraturan perundangan yang merupakan produk hukum nasional dimulai dari terbitnya Peraturan Pemerintah Pengganti Undang-

6 Dr. M. Hadi Shubhan, 2008, Hukum Kepailitan (Prinsip, Norma, dan Praktik di Peradilan), Cet. I, Penerbit Kencana Prenada media Group, Jakarta, hlm. 34 
Undang (PERPU) No. 1 tahun 1998 tentang Perubahan Atas Undang - Undang tentang Kepailitan yang kemudian ditingkatkan menjadi Undang-Undang No. 4 Tahun 1998 dan terakhir pada tanggal 18 November 2004 disempurnakan lagi dengan Undang-Undang Nomor 37 Tahun 2004 tentang Kepailitan dan Penundaan Kewajiban pembayaran Utang. ${ }^{7}$

\section{Faillissementverordening}

menentukan putusan pernyataan pailit dikenakan terhadap "De Schuldennar, die in den toestand verkeet dat hij heeft opgehoudente betalen". Terjemahan ketentuan tersebut dalam bahasa Indonesia mempunyai beberapa versi. Pertama, “ setiap debitor (orang yang berutang) yang tidak mampu membayar utangnya yang berada dalam keadaan berhenti membayar kembali utang tersebut..." Kedua, "Setiap berutang yang berada dalam keadaan telah berhenti membayar utang-utangnya.." Ketiga, "Setiap debitor yang berada dalam keadaan berhenti membayar utangutangnya.." Meskipun terdapat beberapa terjemahan, namun tidak ada yang secara tegas mendefinisikan apa yang dimaksud dengan utang. ${ }^{8}$

Hubungan hukum antara debitor dan kreditor adalah lahir karena perikatan

7 Sri Rejeki Hartono, 2008, Hukum Kepailitan, UMM Press, Malang, hlm. 10

$8 \quad$ Siti Anisa, 2008, Perlindungan Kepentingan Kreditor dan Debitor Dalam Hukum Kepailitan Di Indonesia, Cet I, Penerbit Total Media, Yogyakarta, hlm. 54.
ISSN Cetak \& Online : 2355-5831/ 2355-99.34

serta menimbulkan hak dan kewajiban secara timbal balik. Pihak yang satu mempunyai hak untuk menuntut sesuatu dari pihak yang lain, dan pihak yang lain itu wajib memenuhi tuntutan itu, dan sebaliknya. Dalam hal ini apabila ada salah satu pihak yang melakukan perbuatan tidak diketahui atau ada unsur ketidakjujuran dalam melaksanakan perjanjian tersebut ini yang dikatakan sebagai moral hazard.

Tidak hanya keuntungan korporasi yang dijadikan tujuan dalam melakukan moral hazard melainkan ada kepentingan pribadi yang menjadi pemicu kerugian dalam korporasi. Kerugian inilah yang mengakibatkan suatu korporasi dirundung masalah seperti tidak dapat meluniasi utang dari beberapa kreditor atau bahkan tidak sanggung membayar angsurat yang telah sampai waktu untuk dibayarkan.

Keadaan seperti ini yang nantinya akan dijadikan modus oleh beberapa pihak pelaku modus moral hazard dengan adanya kebijakan moraturium pailit dan Penundaan Kewajiban Pembayaran Utang (PKPU) yang otoritasnya berada di tangan pemerintah seolah Pemerintah meyakini permasalahan pelunasan utang tersebut adalah murni dari ketidak sanggupan dari korporasi. Justru permasalahan ini ditimbulkan karena kesengajaan oleh 
pelaku modus moral hazard yang mengambil keuntungan dari momen ini.

Asas hukum Hukum Kepailitan Indonesia secara umum diatur dalam Pasal 1131 KUH Perdata dan asas khusus dimuat dalam Undang-Undang Nomor 37 Tahun 2004 tentang Kepailitan dan Penundaan Kewajiban Pembayaran Utang. ${ }^{9} \quad$ Kepailitan ini tidak hanya menimpa terhadap perorangan namun juga perusahaan. Perusahaan atau korporasi yang dinyatakan pailit pada saat ini akan membawa dampak dan pengaruh buruk, bukan hanya pada perusahaan itu saja namun juga dapat berakibat global.

Kepailitan berdasarkan Pasal 1 angka 1 Undang - Undang Nomor 37 Tahun 2004 Tentang Kepailitan Dan Penundaan Kewajiban Pembayaran Utang Kepailitan adalah sita umum atas semua kekayaan Debitor Pailit yang pengurusan dan pemberesannya dilakukan oleh Kurator di bawah pengawasan Hakim Pengawas sebagaimana diatur dalam Undang-Undang ini.

Adapun seorang debitor dapat dinyatakan pailit berdasarkan ketentuan Pasal 2 ayat (1) UU Kepailitan dan PKPU apabila memenuhi syarat-syarat sebagai berikut : pertama, Debitor yang mempunyai dua atau lebih kreditor dan tidak membayar lunas sedikitnya satu

9 Syamsudin Sinaga, 2012, Hukum Kepailitan Indonesia, Tatanusa, Jakarta, hlm. 34
ISSN Cetak \& Online : 2355-5831/ 2355-99.34 utang yang telah jatuh waktu dan dapat ditagih, dinyatakan pailit dengan putusan Pengadilan, baik atas permohonannya sendiri maupun atas permohonan satu atau lebih kreditornya. Keberadaan dua kreditor merupakan syarat yang disebutkan dalam Undang-Undang Kepailitan dan PKPU Nomor 37 Tahun 2004. Ketentuan Pasal 1132 KUHPerdata bahwa harta kekayaan debitor harus dibagi secara adil kepada setiap kreditor.

Kedua, debitor paling sedikit tidak membayar satu utang kepada salah satu kreditor yang diartikan sebagai suatu keadaan bahwa debitor tidak membayar utangnya yang seharusnya dibayar. Apabila baru satu kali tidak membayar, maka belum dapat dikatakan suatu keadaan berhenti membayar. Keadaan berhenti membayar adalah adanya lebih dari satu kali tidak membayar, keadaan ini merupakan syarat mutlak untuk pernyataan pailit. Keadaan berhenti membayar utangutang harus diartikan sebagai suatu keadaan bahwa debitor tidak membayar utangnya yang seharusnya dia bayar. Apabila dia baru satu kali tidak membayar, maka dia belum dapat dikatakan suatu keadaan berhenti membayar. Keadaan berhenti membayar adalah adanya lebih dari satu kali tidak membayar, keadaan ini merupakan syarat mutlak untuk pernyataan pailit. 


\section{IURNAL JENDELA HUKUM}

Ketiga, utang yang belum dibayar telah jatuh waktu dan sudah dapat ditagih yang memiliki pengertian berbeda. Utang yang telah jatuh waktu dengan sendirinya menjadi utang yang dapat ditagih, namun utang yang telah dapat ditagih belum tentu utang yang telah jatuh waktu. Utang dikatakan jatuh waktu apabila telah sampai jadwal waktunya untuk dilunasi oleh Debitor. Suatu utang sekalipun waktunya belum tiba, tetapi mungkin saja utang itu dapat ditagih karena terjadi wanprestasi sebagaimana yang ditentukan dalam perjanjian. Utang jatuh waktu dan dapat ditagih memiliki pengertian yang berbeda. Utang yang telah jatuh waktu dengan sendirinya menjadi utang yang dapat ditagih, namun utang yang telah dapat ditagih belum tentu utang yang telah jatuh waktu. Utang dikatakan jatuh waktu apabila telah sampai jadwal waktunyan untuk dilunasi oleh debitor. Suatu utang sekalipun waktunya belum tiba, tetapi mungkin saja utang itu dapat ditagih karena terjadi wanprestasi sebagaimana yang ditentukan dalam perjanjian.

Salah satu pihak yang terlibat dalam perkara kepailitan adalah pihak pemohon pailit yang dapat mengajukan permohonan pailit ke Pengadilan Niaga berdasarkan ketentuan Pasal 2 ayat (1) UU Kepailitan dan PKPU Nomor 37 Tahun 2004 yaitu debitor yang mempunyai dua atau lebih kreditor dan tidak membayar
ISSN Cetak E Online : 2.355-5831/ 2355-99.34

lunas sedikitnya satu utang yang telah jatuh waktu dan dapat ditagih, dinyatakan pailit dengan putusan pengadilan, baik atas permohonannya sendiri maupun permohonan satu atau lebih kreditornya.

Selain membahas mengenai masalah pailit dalam Undang-Undang Nomor 37 Tahun 2004 Tentang Kepailitan Dan Penundaan Kewajiban Pembayaran Utang membahas juga mengenai penundaan kewajiban pembayaran utang. Penundaan kewajiban pembayaran utang dapat diajukan oleh debitur maupun kreditor yang memiliki itikad baik upaya ini hanya dapat diajukan sebelum putusan pernyataan pailit ditetapkan oleh pengadilan. Apabila permohonan pernyataan pailit dan permohonan penundaan kewajiban pembayaran utang diperiksa secara bersamaan maka permohonan penundaan kewajiban pembayaran utang harus diputus terlebih dahulu.

Adanya status pailit terhadap suatu perusahaan berdasarkan syarat dan Putusan Pailit pada Pasal 2 ayat (1) Undang - Undang Nomor 37 Tahun 2004 Tentang Kepailitan Dan Penundaan Kewajiban Pembayaran Utang Debitor yang mempunyai dua atau lebih Kreditor dan tidak membayar lunas sedikitnya satu utang yang telah jatuh waktu dan dapat ditagih, dinyatakan pailit dengan putusan Pengadilan, baik atas permohonannya 
sendiri maupun atas permohonan satu atau lebih kreditornya.

Pemberian Penundaan Kewajiban Pembayaran Utang dan Akibatnya dalam Pasal 222 Undang - Undang Nomor 37 Tahun 2004 Tentang Kepailitan Dan Penundaan Kewajiban Pembayaran Utang, penundaan kewajiban pembayaran utang diajukan oleh debitor yang mempunyai lebih dari satu kreditor atau oleh kreditor. Sedangkan debitor yang tidak dapat atau memperkirakan tidak akan dapat melanjutkan membayar utang-utangnya yang sudah jatuh waktu dan dapat ditagih, dapat memohon penundaan kewajiban pembayaran utang, dengan maksud untuk mengajukan rencana perdamaian yang meliputi tawaran pembayaran sebagian atau seluruh utang kepada Kreditor.

Kreditor yang memperkirakan bahwa debitor tidak dapat melanjutkan membayar utangnya yang sudah jatuh waktu dan dapat ditagih, dapat memohon agar kepada debitor diberi penundaan kewajiban pembayaran utang, untuk memungkinkan debitor mengajukan rencana perdamaian yang meliputi tawaran pembayaran sebagian atau seluruh utang kepada kreditornya.

Oleh sebab itu, lembaga kepailitan merupakan salah satu kebutuhan pokok di dalam aktivitas bisnis karena adanya status pailit merupakan salah satu sebab pelaku bisnis keluar dari pasar.
ISSN Cetak \& Online : 2355-5831/2355-9934

Apabila pelaku bisnis sudah tidak mampu lagi untuk bermain di arena pasar, maka dapat keluar dari pasar. Di dalam hal seperti inilah kemudian lembaga kepailitan itu berperan. ${ }^{10}$

Hanya sebatas pada ruang solutif saja bagi para kreditor atau debitor terkait mekanisme PKPU untuk melakukan diskusi dan negosiasi. Namun yang menjadi simpul pada permasalahan ini adalah modus moral hazard yang berindikasi bahwa melalui modus moral hazard yang memiliki syarat mudah dalam pengajuan permohonan PKPU dan pernyataan pailit.

Konsep Law As Tool Of Social Control, yakni hukum sebagai control sosial, hukum lahir dari masyarakat untuk masyarakat maka sudah sejatinya produk hukum yang dilahirkan tidak hanya ditujukan untuk keuntungan pihak yang berkepentingan. Hukum sebagai alat kontrol sosial memberikan arti bahwa ia merupakan sesuatu yang dapat menetapkan tingkah laku manusia. Tingkah laku ini dapat didefenisikan sebagai sesuatu yang menyimpang terhadap aturan hukum. Sebagai akibatnya, hukum dapat memberikan sanksi atau tindakan terhadap si pelanggar. ${ }^{11}$ Sehingga hukum dapat

10 Sudargo Gautama, 1998, Komentar Atas Peraturan Kkepailitan Untuk Indonesia, Citra Aditya Bakti, Bandung, hlm. 205

11 Ashadi L.Diab, 2014, Peranan Hukum Sebagai Social Control, Social Engineering Dan 


\section{IURNAL JENDELA HUKUM}

ISSN Cetak E Online : 2355-5831/ 2355-99.34

menetapkan sanksi bagi pelaku yang melakukan prilaku menyimpang. Hal ini berarti bahwa hukum mengarahkan agar masyarakat berbuat secara benar menurut aturan sehingga ketentraman terwujud.

Hukum, di samping bukan satusatunya alat kontrol sosial, juga sebagai alat pengendali memainkan peran pasif. Artinya bahwa hukum menyesuaikan diri dengan kenyataan masyarakat yang dipengaruhi oleh keyakinan dan ajaran falsafat lain yang diperpeganginya. ${ }^{12}$

Dari sudut sifatnya sosial control bersifat preventif atau represif, preventif merupakan usaha pencegahan terhadap terjadinya gangguan kepastian dan keadilan. Sementara represif adalah bertujuan untuk mengembalian keserasian hukum dengan masyarakat, proses sosial control dapat dilaksanaakan tanpa kekerasan ataupun paksaan (coercive). Fungsi sosial control yakni membentuk kaidah baru dengan menggantikan kaidah lama. Dalam compultion diciptakan situasi seseorang terpaksa taat pada suatu aturan atau mengubah sikapnya menghasilkan kepatutan secara tidak langsung dan tanpa disadari.

Arah kebijakan hukum pada moraturium pailit dan Penundaan

Social Welfare, Jurnal Al-'Adl Vol. 7 No. 2, Juli 2014, hlm. 58

${ }^{12}$ Ibid.
Kewajiban Pembayaran Utang (PKPU) tidak selaras dengan konsep Law As Tool Of Social Control dimana fungsi sosial dari hukum yang diciptakan untuk mengembalian keserasian hukum dengan masyarakat yang sejatinya semua unsur penunjang dalam dunia bisnis tidak hanya pihak debitor ataupun kreditor saja. Melainkan, dampak dari segala aspek yang akan ditimbulkan dari moraturium pailit dan Penundaan Kewajiban Pembayaran Utang (PKPU) membuat kedudukan pemberi kredit seperti sektor perbankan terancam. Karena tidak mendapatkan penyelesaian dari masalah ini dan justru akan memperburuk kondisi perekonomian nasional. Dengan dibawa sertanya ciri-ciri individual dalam interaksi sosial, konflik merupakan situasi yang wajar dan tidak satupun dalam dunia hukum bisnis yakni adanya Conflict Interest.

Setiap organisasi atau korporasiatau perusahaan, perbedaan pendapat sering kali disengaja atau dibuat sebagai salah satu strategi para pemimpin untuk melakukan perubahan. Perubahan tersebut dapat dilakukan dengan menciptakan sebuah konflik. Akan tetapi, konflik juga dapat terjadi secara alami karena adanya kondisi obyektif yang dapat menimbulkan terjadinya konflik.

Tidak hanya itu Conflict Interest yang sengaja diciptakan justru dilakukan melalui modus moral hazard yang 


\section{IURNAL JENDELA HUKUM}

dilakukan oleh pihak berkepentingan secara tidak jujur dalam jalannya suatu perusahaan. Perbuatan ini yang dikatakan sebagai itikad tidak baik dalam suatu pemenuhan prestasi nantinya akan berakibat pula pada isi dari perjanjian tersebut.

\section{KESIMPULAN}

Perumusan kebijakan moraturium pailit dan Penundaan Kewajiban Pembayaran Utang (PKPU) bukan merupakan hal yang urgen untuk diberlakukan dalam bentuk Perppu karena sudah diatur dalam Undang - Undang Nomor 37 Tahun 2004 Tentang Kepailitan Dan Penundaan Kewajiban Pembayaran Utang. Apabila kebijakan ini diberlakukan maka secara yuridis otoritas legal untuk permohonan pengajuan pailit dan permohonan Penundaan Kewajiban Pembayaran Utang (PKPU) berada di tangan Pemerintah. Dan tendensi dari hal ini yang awalnya bertujuan untuk memberikan peluang kepada debitor agar dapat menyelesaikan permasalahan utang dalam kurun waktu tertentu justru akan berujung pada kerugian yang dialami oleh pihak lain, misalnya seperti industri Perbankan. Bukan hanya kerugian, namun pola ini juga membawa pihak berkepentingan tersebut untuk menjadikan ini sebagai momentum untuk menguntungkan diri pribadi melalui modus moral hazard.
ISSN Cetak \& Online : 2355-5831/2355-99.34

Berdasarkan konsep Law As Tool

Of Social Control, yakni hukum sebagai control sosial, hukum lahir dari masyarakat untuk masyarakat maka sudah sejatinya produk hukum yang dilahirkan tidak hanya ditujukan untuk keuntungan pihak yang berkepentingan. Melaikan harus pula dapat dijadikan anomali berperilaku dan bertindak yang tidak menyebabkan kerugian pihak lain.

\section{DAFTAR BACAAN}

\section{Buku}

Dr. M. Hadi Shubhan, 2008, Hukum Kepailitan (Prinsip, Norma, dan Praktik di Peradilan), Cet. I, Penerbit Kencana Prenada media Group, Jakarta

Gatot Supramono, Perjanjian Utang Piutang, Cet. I, Penerbit Kencana Prenadamedia Group, Jakarta 2013

M. Hadi Subhan, 2008, Hukum Kepailitan Prinsip, Norma, dan Praktik di Peradilan, Kencana, Jakarta

Prof. Dr. Sutan Remy Sjahdeini, 2010, Hukum Kepailitan Memahami UU No.37 Tahun 2004 tentang Kepeilitan, Pustaka Utama Grafiti, Jakarta

Ridwan Khairandy, 2013, Pokok-Pokok Hukum Dagang Indonesia, FH UII Press, Yogyakarta

Siti Anisa, 2008, Perlindungan Kepentingan Kreditor dan Debitor Dalam Hukum Kepailitan Di Indonesia, Cet I, Penerbit Total Media,Yogyakarta

Sri Rejeki Hartono, 2008, Hukum Kepailitan, UMM Press, Malang

Sudargo Gautama, 1998, Komentar Atas Peraturan Kkepailitan Untuk Indonesia, Citra Aditya Bakti, Bandung. 


\section{IURNAL JENDELA HUKUM}

ISSN Cetak E Online : 2355-5831/ 2355-9934

Syamsudin Sinaga, 2012, Hukum Kepailitan Indonesia, Tatanusa, Jakarta

\section{Peraturan dan Putusan Hukum}

Kitab Undang - Undang Hukum Perdata (KUHP)

Undang - Undang Nomor 37 Tahun 2004 Tentang Kepailitan Dan Penundaan

Jurnal

Kewajiban Pembayaran Utang

Ashadi L.Diab, 2014, Peranan Hukum Sebagai Social Control, Social Engineering Dan Social Welfare, Jurnal Al-'Adl Vol. 7 No. 2, Juli 2014

\section{Laman}

Vendy Yhulia Susanto, 2021, Para pakar soroti wacana moratorium pengajuan PKPU dan Kepailitan, diakses dari https://nasional.kontan.co.id/news/ para-pakar-soroti-wacanamoratorium-pengajuan-pkpu-dankepailitan pada tanggal 02 September 2021 Pukul 13.08 WIB. 